\title{
Analisis Jarak Genetik Sapi Bali pada Tiga Kecamatan di Kabupaten Merangin Provinsi Jambi
}

\author{
Analysis of the Genetic Distance of Bali Cattle in Three Districts \\ in Merangin Regency, Jambi Province
}

\author{
A. S. Wilastra, Gushairiyanto, S. Erina, \& Depison* \\ Program Studi Peternakan Fakultas Peternakan Universitas Jambi \\ Jl. Jambi-Ma. Bulian KM 15 Mendalo Darat Jambi 36361 \\ *Email korespondensi: depison.nasution@unja.ac.id
}

\author{
- Diterima: 14 Juli 2020 • Direvisi: 13 November 2020 • Disetujui: 17 Desember 2020
}

\begin{abstract}
ABSTRAK. Sapi potong merupakan salah satu ruminansia yang memiliki potensi besar sebagai sumber protein hewani di Indonesia. Tujuan penelitian ini adalah untuk mengetahui bobot badan, pertambahan bobot badan harian, dan jarak genetik sapi Bali pada tiga Kecamatan di Kabupaten Merangin Provinsi Jambi. Materi penelitian adalah sapi Bali umur I1 (12-24 bulan), sebanyak 180 ekor yang terdiri dari 30 ekor jantan dan 30 ekor betina di setiap kecamatan. Metode penelitian adalah metode survei, teknik pengambilan sampel secara purposive sampling dengan jumlah sampel sebanyak 180 ekor, yang terdiri dari 30 jantan dan 30 betina dan tidak dalam keadaan bunting. Data yang dihimpun meliputi bobot badan, pertambahan bobot badan harian dan morfometrik di tiga kecematan. Data bobot badan, rata-rata pertambahan bobot badan dan morfometri dianalisis menggunakan uji beda rata-rata (uji-t). Vektor nilai rata rata morfometrik sapi Bali di tiga kecamatan dianalisis menggunakan uji statistik T2 Hotelling. Penciri ukuran dan bentuk tubuh sapi Bali dianalisis menggunakan Analisis Komponen Utama. Fungsi diskriminan dapat digunakan untuk menganalisis jarak genetik yang dapat membentuk pohon filogenetik. Hasil penelitian ini menunjukkan bobot badan, rata-rata pertambahan bobot badan dan morfometri sapi Bali di Kecamatan Pamenang dan Bangko berbeda tidak nyata (P> 0,05), sedangkan dengan kecamatan Margo Tabir berbeda nyata $(\mathrm{P}<0,05)$ dengan Kecamatan Pamenang dan Bangko. Penciri ukuran dan bentuk sapi Bali di ketiga kecamatan adalah lingkar dada dan tinggi pundak. Kesimpulan penelitian adalah jarak genetik terjauh antara sapi Bali di Kecamatan Bangko dan Margo Tabir $(2,6271)$, dikuti antara Kecamatan Pemenang dan Margo Tabir $(2,1357)$, jarak genetik terdekat antara sapi Bali di Kecamatan Pamenang dan Bangko $(0,5772)$.
\end{abstract}

Kata kunci: Sapi Bali, jarak genetik, morfometrik, analisis komponen utama

ABSTRACT. The beef cattle are one of the ruminants that have great potential in providing sources of animal protein in Indonesia. The purpose of this research was to determine the body weight, average daily gain, and genetic distance of Bali cattle in three sub-districts of Merangin district, Jambi Province. The research method was a survey method with purposive sampling technique, as many as 180 samples consisting of 30 males and 30 females in each sub-district and were not pregnant. Data collected include body weight, avarege daily gain and morphometrics between three sub-districs. The data body weight, avarege daily gain and morphometrics were analyzed using the average difference test (t-test). The average value vector body measurement of Bali catlle in three subdistrict was analyzed using the $T^{2}$ Hotelling statistical test. The main component analysis statistical test was used to determine the characteristics of the body shape and size of Bali cattle. The discriminant function can be used to analyze genetic distances, which can form a phylogenetic tree. The results of this research indicate of body weight, average daily gain and morphometrics of Bali cattle in sub-district Pamenang not significantly different $(P>0,05)$ from Bangko sub-district, but were significantly different $(P<0.05)$ with Margo Tabir sub-district. The characteristics of the size and shape of Bali cattle in the three sub-districts are chest circumference and shoulder height. The conclusion from this research is the genetic distance between Bali cattle in Pamenang and Bangko Sub-districts (0.57), with Margo Tabir Subdistrict (2.13), and genetic distance between Bangko sub-district and Margo Tabir sub-district (2.62).

Keywords: Bali cattle, genetic distance, morphometrics, principal component analysis

\section{PENDAHULUAN}

Ternak ruminansia merupakan salah satu komoditas sektor peternakan yang banyak peminatnya setelah ternak unggas dan memiliki peranan penting dalam meningkatkan pendapatan masyarakat khususnya bagi peternak, serta dapat memperluas lapangan pekerjaan. Salah satu bangsa ruminansia dengan populasi tertinggi di Indonesia adalah sapi potong. BPS Indonesia (2018) melaporkan 
populasi sapi potong di Indonesia mencapai 17.050.006 ekor.

Populasi sapi potong tersebut diharapkan dapat memenuhi kebutuhan protein hewani bagi masyarakat Indonesia dan penyebarannya cukup merata di berbagai daerah, salah satunya di Provinsi Jambi. Sapi potong di Provinsi Jambi pada tahun 2014 mencapai 136.638 ekor, kemudian meningkat secara signifikan pada tahun 2018 menjadi 161.667 ekor dengan kenaikan rata-rata sebesar $2,27 \%$ per tahun (BPS Provinsi Jambi, 2018). Data tersebut menunjukkan adanya potensi pengembangan sapi potong di Provinsi Jambi. Populasi sapi potong di daerah ini tersebar hampir di semua kabupaten, termasuk di Kabupaten Merangin dengan populasi sebanyak 16.703 ekor pada tahun 2017 (BPS Kabupaten Merangin, 2018).

Di Kabupaten Merangin sapi potong dipelihara oleh masyarakat terdiri dari berbagai bangsa, diantaranya adalah bangsa sapi Bali. Populasi sapi Bali di Kabupaten Merangin menyebar di berbagai kecamatan, diantaranya di Kecamatan Pamenang, Bangko dan Margo Tabir. Sistem pemeliharaan di Kecamatan Pamenang secara semi intensif (siang digembalakan dan malam dikandangkan dan diberi hijauan pakan dan konsentrat) dengan sistem perkawinan secara Inseminasi Buatan (IB). Di kecamatan Bangko sistem pemeliharaan secara intensif dan perkawinan secara IB. Di Kecamatan Margo Tabir, sistem pemeliharaan secara semi intensif (siang digembalakan dan malam dikandangkan namun tidak diberi pakan) dan sistem perkawinan secara alami. Adanya perbedaan manajemen pemeliharaan dan sistem perkawinan pada Kecamatan Pamenang, Bangko dan Margo Tabir diduga akan menyebabkan perbedaan produktivitas. Salah satu upaya yang dapat dilakukan untuk mengetahui tingkat produktivitas sapi Bali maka perlu dilakukan karakterisasi.

Karakterisasi memiliki peranan penting dalam upaya mempertahankan, menggali dan mengembangkan potensi sumberdaya masingmasing ternak, sehingga dapat digunakan untuk mengidentifikasi performa sifat kuantitatif pada suatu individu. Performa sifat kuantitatif merupakan suatu sifat yang dipengaruhi oleh banyak pasang gen, dapat diukur tetapi tidak dapat diamati secara langsung. Sifat kuantitatif meliputi : bobot badan, pertambahan bobot badan dan morfometrik.

Morfometrik adalah studi yang berhubungan dengan variasi, perubahan bentuk dan ukuran dari suatu spesies, meliputi pengukuran panjang dan analisis kerangka (Komariah, 2016). Karakteristik morfometrik meliputi: tinggi pundak, panjang badan, lebar dada, lingkar dada, dalam dada, tinggi pinggul dan kronial (Heryani et al., 2018). Pendekatan morfometrik dapat digunakan untuk menganalisis jarak genetik.

Jarak genetik adalah tingkat perbedaan gen (perbedaan genomik) yang diukur melalui ukuran numerik pada suatu populasi atau spesies tertentu. Jarak genetik diukur dengan berbagai parameter. Jarak genetik yang kecil menunjukkan hubungan genetik yang dekat dan sebaliknya, jarak genetik yang besar menunjukkan hubungan genetik yang jauh (Pinem et al., 2015). Hasil jarak genetik dapat digunakan untuk mengetahui pohon dendogram. Pohon dendogram yaitu diagram cabang yang menggambarkan suatu susunan hubungan genetik pada suatu populasi atau kelompok tertentu. Informasi jarak genetik dan hubungan kekerabatan antara populasi sapi Bali sangat diperlukan sebagai acuan dasar dalam merumuskan program pemuliaan dan pengembangan plasma nutfah sapi Bali dimasa yang akan datang.

Berdasarkan uraian di atas maka tujuan penelitian ini adalah untuk mengetahui performa sifat kuantitatif dan jarak genetik antar tiga populasi sapi Bali di Kabupaten Merangin Provinsi Jambi.

\section{MATERI DAN METODE}

Penelitian ini telah dilaksanakan di Kabupaten Merangin Provinsi Jambi. Materi yang digunakan pada penelitian ini dapat dilihat pada Tabel 1. 
Tabel 1. Sapi bali yang digunakan pada penelitian

\begin{tabular}{cccc}
\hline No & Kecamatan & Umur & Jumlah \\
\hline 1 & Pamenang & I1 (12-24) & 60 \\
2 & Bangko & I1 (12-24) & 60 \\
3 & Margo Tabir & I1 (12-24) & 60 \\
\hline
\end{tabular}

Tabel 1 menunjukkan total sampel yang dibutuhkan dari tiga kecamatan yaitu sebanyak 180 ekor, sehingga pada setiap kecamatan membutuhkan sapi Bali sebanyak 60 ekor, terdiri dari 30 ekor jantan dan 30 ekor betina. Peralatan yang digunakan: alat tulis, tongkat dan pita ukur, timbangan digital dan kamera.

Penelitian ini menggunakan metode survey dengan teknik pengambilan sampel secara pusposive sampling, dengan kriteria berdasarkan perbedaan sistem pemeliharaan dan perkawinan yang diterapkan, jumlah populasi sapi Bali terbanyak di setiap desa pada masing-masing kecamatan, umur 12-24 bulan (I1) dan tidak dalam keadaan bunting dan sakit.

Data yang dihimpun meliputi:

1. Bobot Badan (BB) dihitung dan ditimbang pada pagi hari sebelum sapi diberi makan $(\mathrm{kg})$.

2. Pertambahan Bobot Badan Harian (PBBH) dihitung dengan menggunakan rumus sebagai berikut: bobot akhir dikurang bobot awal (kg) dibagi jarak penimbangan yaitu 30 hari.

$$
\mathrm{PBBH}=\frac{\text { BB II-BB I }}{\text { Waktu (hari) }}
$$

\section{Keterangan:}

PBBH = Pertambahan bobot badan harian

BB II = Bobot badan penimbangan akhir
BB I = Bobot badan penimbangan awal

Waktu = Jarak (hari) waktu penimbangan pertama dan kedua.

3. Panjang Badan (PB) diukur dari tepi tulang processus spinocus sampai dengan benjolan tulang tapis/tulang duduk (os ischium), dengan menggunakan tongkat ukur (cm).

4. Tinggi Pundak (TP) diukur dari titik tertinggi pundak sampai tanah dengan menggunakan tongkat ukur $(\mathrm{cm})$.

5. Lingkar Dada (LiD) diukur melingkar pada rongga dada di belakang sendi bahu (os scapula) menggunakan pita ukur ( $\mathrm{cm})$.

6. Dalam Dada $(\mathrm{DaD})$ diukur mulai dari bagian tertinggi pundak sampai dengan dasar dada $(\mathrm{cm})$.

7. Lebar Dada (LeD) diukur antara tuberitas humeri sinister dan dexter, dengan menggunakan tongkat ukur $(\mathrm{cm})$.

8. Lingkar Kanon (LK) diukur dengan menggunakan pita ukur mulai dari tengah-tengah tulang pipa kaki depan sebelah kiri $(\mathrm{cm})$.

9. Tinggi Pinggul (TPi) diukur dengan tongkat ukur mulai dari jarak tertinggi pinggul (os sacrum) tegak lurus dengan permukaan tanah $(\mathrm{cm})$.

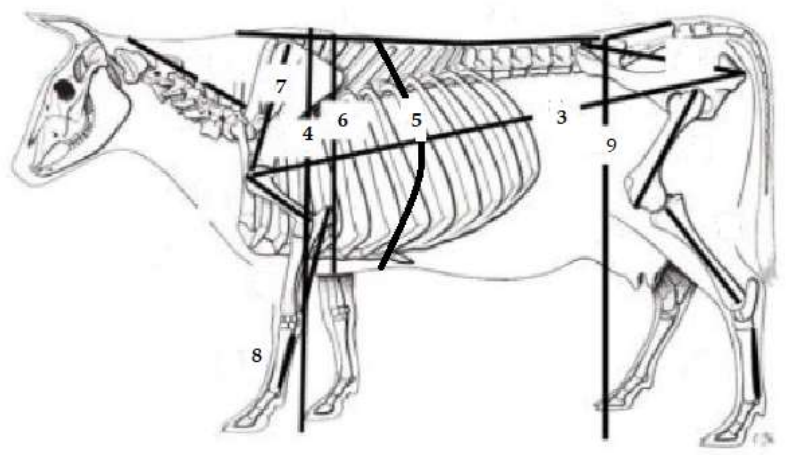

Gambar 1. Bagian tubuh yang diukur 
Metode pengukuran pada penelitian ini mengikuti petunjuk Heriyadi (2012) yang meliputi: Tinggi Pundak (TP), Lingkar Kanon (LK), Panjang Badan (PB), Dalam Dada (DaD), Lingkar Dada (LD), Lebar Dada (LeD) dan Tinggi Pinggul (TPi). Lalu data tersebut dikelompokan berdasarkan kecamatan, selanjutnya data akan dianalisis deskriptif untuk mendapatkan data mean, standar deviasi, dan koefisien varian.

Mean adalah nilai yang mewakili sekelompok data, rumus yang digunakan yaitu sebagai berikut:

$$
\bar{x}=\frac{1}{n} \sum_{i=1}^{n} x_{i}
$$

Kemudian untuk mencari nilai standar deviasi, rumus yang digunakan yaitu:

$$
s=\sqrt{\frac{1}{n-1} \sum_{i=1}^{n}\left(x_{i}-\bar{x}\right)^{2}}
$$

Koefisien varian dapat dihitung dengan menggunakan rumus sebagai berikut:

$$
K V=\frac{s}{\bar{x}}
$$

\footnotetext{
Keterangan:

$\overline{\mathrm{x}} \quad=$ nilai rata-rata

$\mathrm{s} \quad=$ standar deviasi

$\mathrm{KV}=$ koefisien varian/ koefisien keragaman

Selanjutnya data akan dikoreksi, hal ini bertujuan untuk menghilangkan salah satu faktor pembeda antar sampel yaitu data jenis kelamin, ketika sudah dikoreksi, data hasil koreksi tersebut akan digabungkan dengan data sapi Bali jantan, sehingga parameter yang dibandingkan pada sampel penelitian ini yaitu hanya data sapi Bali antar kecamatan. Rumus yang digunakan untuk koreksi data mengikuti penelitian Depison (2010) yaitu sebagai berikut:
}

$$
\mathrm{R}=\frac{x^{-} \mathrm{i}}{x^{-} \mathrm{j}}
$$

Kemudian

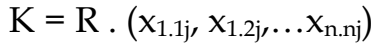

\section{Keterangan:}

$$
\begin{aligned}
\mathrm{R} & =\text { rataan antar jenis kelamin } \\
\overline{\mathrm{x}}_{\mathrm{i}} & =\text { rataan pada data jantan } \\
\overline{\mathrm{x}}_{\mathrm{j}} & =\text { rataan pada data betina } \\
\mathrm{K} & =\text { koreksi } \\
\mathrm{x}_{1.1 \mathrm{j}} \quad= & \text { data baris pertama pada kolom } \\
& \text { pertama sapi Bali betina }
\end{aligned}
$$

Data sapi Bali jantan dan sapi Bali hasil koreksi yang sudah digabungkan dan mewakili Kecamatan Pamenang, Bangko dan Margo Tabir kemudian dianalisis menggunakan uji beda rata (uji-t) dengan rumus (Gaspersz, 2006);

$$
\mathrm{t}=\frac{\bar{X}_{1}-\bar{X}_{2}}{\sqrt{\frac{\sum\left(X_{J 1}-\bar{X}_{1}\right)^{2}}{n_{1}\left(n_{1}-1\right)}+\frac{\sum\left(X_{J 2}-\bar{X}_{2}\right)^{2}}{n_{2}\left(n_{2}-1\right)}}}
$$

Keterangan:

$\mathrm{t}=$ nilai $\mathrm{t}$ hit

$\bar{X}_{1}=$ nilai rata-rata sampel dari kelompok ternak pada kecamatan pertama,

$\bar{X}_{2}=$ nilai rata-rata sampel dari kelompok ternak pada kecamatan kedua,

$\mathrm{X}_{\mathrm{j} 1}=$ standar deviasi pada kelompok kecamatan pertama,

$\mathrm{X}_{\mathrm{j} 2}=$ standar deviasi pada kelompok kecamatan kedua,

$\mathrm{n}_{1}=$ total sampel yang digunakan kelompok ternak kecamatan pertama,

$\mathrm{n}_{2}=$ total sampel pada kelompok kecamatan kedua.

Apabila analisis univariat mendapatkan hasil yang tidak seragam antar variabel pada suatu kecamatan, maka analisis akan dilanjutkan dengan analisis multivariat statistik $\mathrm{T}^{2}$-Hotelling, rumus yang digunakan sebagai berikut:

$$
T^{2}=\frac{n_{1} n_{2}}{n_{1}+n_{2}}\left(\overline{\left(X_{1}\right.}-\overline{X_{2}}\right) S_{G}^{-1}\left(\overline{\overline{X_{1}}}-\overline{\overline{X_{2}}}\right)
$$

Kemudian dilanjutkan 


$$
F=\frac{n_{1}+n_{2}-p-1}{\left(n_{1}+n_{2}-2\right) p} T^{2}
$$

akan berdistribusi F dengan derajat bebas

$$
\mathrm{V} 1=\mathrm{p} \text { dan } \mathrm{V} 2=\mathrm{n} 1+\mathrm{n} 2-\mathrm{p}-1
$$

Keterangan:

$\mathrm{T}^{2}=$ nilai statistik $\mathrm{T}^{2}$-Hotelling

$\mathrm{F} \quad=$ nilai $\mathrm{F}$ hitung untuk $\mathrm{T}^{2}$-Hotelling

$\mathrm{n}_{1} \quad=$ jumlah data yang diamati pada kelompok ternak kecamatan pertama

$\mathrm{n}_{2} \quad=$ jumlah data yang diamati pada kelompok ternak kecamatan kedua

$\mathrm{X}_{1}=$ vektor dari rataan variabel acak pada kelompok ternak kec. pertama

$\mathrm{X}_{2}=$ vektor dari rataan variabel acak pada kelompok ternak kec. kedua

SG-1 = matriks invers dari matriks kovarian (invers dari matriks SG)

$\mathrm{P} \quad$ = banyaknya variabel yang digunakan

Bila uji statistik $\mathrm{T}^{2}$-Hotelling menunjukkan hasil yang berbeda nyata $(\mathrm{P}<0,05)$, maka pengolahan data akan dilanjutkan pada masing-masing kecamatan dengan menggunakan Analisis Komponen Utama (AKU). AKU adalah teknik statistik yang digunakan pada sekumpulan data yang saling berhubungan. Tujuannya yaitu untuk menemukan sejumlah variabel yang jumlahnya lebih sedikit tanpa menghilangkan karakteristik dari variabel asal, sehingga lebih mudah untuk menginterpretasikan data-data tersebut (Abdurrachman et al., 2014). Analisis komponen utama juga dapat digunakan untuk mengamati perbedaan ukuran dan bentuk tubuh pada setiap kelompok kecamatan. Persamaan ukuran dan bentuk diturunkan dari matriks korelasi. Model matematika yang digunakan untuk analisis ini (Gaspersz, 2006) sebagai berikut:

$$
Y j=a_{1 j} X_{1}+a_{2 j} X_{2}+a_{3 j} X_{3}+\ldots \ldots+a_{7 j} X
$$

Keterangan:

$\mathrm{Yj}_{\mathrm{j}}=$ komponen utama ke-j $(\mathrm{j}=1,2 ; 1=$ ukuran, 2 = bentuk)

$\mathrm{X}_{1,2,3 \ldots}=$ variabel ke $1,2,3 \ldots .7$

$a_{\mathrm{ij}, 2 \mathrm{j}, 3 \mathrm{j}, . .}=$ vektor eigen variable ke-i $(1,2,3 \ldots 7)$ dan komponen utama ke $j$.

Analisis deskriptif, uji beda rata-rata (ujt), uji $\mathrm{T}^{2}$-Hotteling dan Analisis Komponen Utama pada penelitian ini menggunakan aplikasi Minitab 18. Pendekatan jarak Mahalanobis dengan matriks korelasi antar peubah berdasarkan kelompok sapi Bali di tiga Kecamatan Kabupaten Merangin disusun menjadi sebuah matriks yang digunakan untuk mengetahui fungsi diskriminan (Pinem et al., 2015). Fungsi diskriminan dapat digunakan untuk mengetahui persentase kesamaan dan jarak genetik beberapa populasi sapi Bali pada lokasi yang berbeda. Dendogram jarak genetik sapi Bali di tiga kecamatan di Kebupaten Merangin Provinsi Jambi dapat dianalisis dengan menggunakan metode UPGMA (Unweight Pair Group Method with Arithmetic) dengan asumsi bahwa laju evolusi antar kelompok sapi Bali adalah sama, aplikasi perangkat lunak yang digunakan yaitu MEGA $\mathrm{X}$.

\section{HASIL DAN PEMBAHASAN}

\section{Bobot Badan dan Pertambahan Bobot Badan Sapi Bali di Tiga Kecamatan}

Bobot badan (BB) dan pertambahan bobot badan harian $(\mathrm{PBBH})$ sapi Bali di Kecamatan Pamenang, Kecamatan Bangko dan Kecamatan Margo Tabir pada umur I1 (12-24 bulan) disajikan pada Tabel 2.

Tabel 2. Rataan bobot badan dan pertambahan bobot badan harian sapi Bali di tiga kecamatan

\begin{tabular}{lccc}
\hline \multirow{2}{*}{ Parameter } & \multicolumn{3}{c}{ Kecamatan } \\
\cline { 2 - 4 } & Pamenang & Bangko & Margo Tabir \\
\hline BB (kg) & $206,07 \pm 15,58^{\mathrm{a}}$ & $203,58 \pm 15,54^{\mathrm{a}}$ & $190,37 \pm 20,36^{\mathrm{b}}$ \\
PBBH (kg/ekor/hari) & $0,26 \pm 0,03^{\mathrm{a}}$ & $0,25 \pm 0,03^{\mathrm{a}}$ & $0,22 \pm 0,05^{\mathrm{b}}$
\end{tabular}

Keterangan: Superskrip huruf yang berbeda pada satu baris yang sama antar kecamatan berarti berbeda nyata $(\mathrm{P}<0,05)$, BB dan PBB (Jarak 1 bulan). 


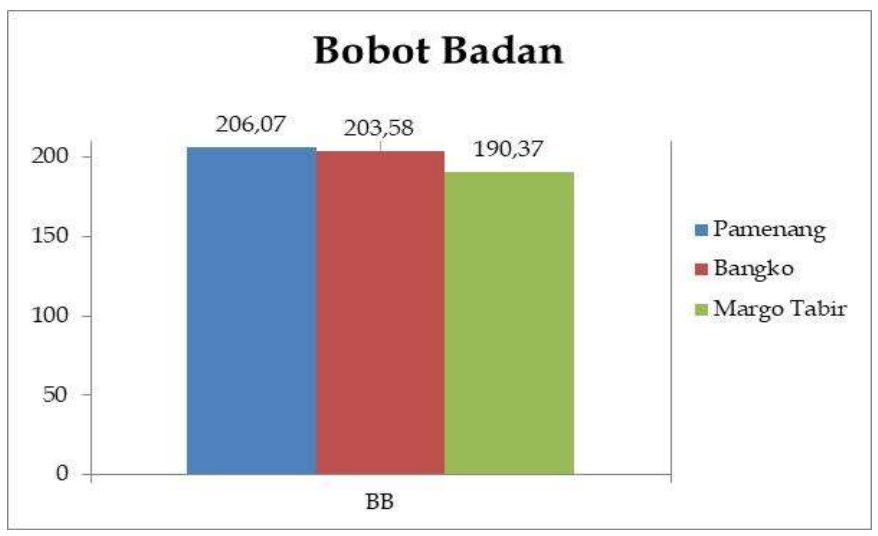

Gambar 2. Bobot badan sapi Bali antar kecamatan

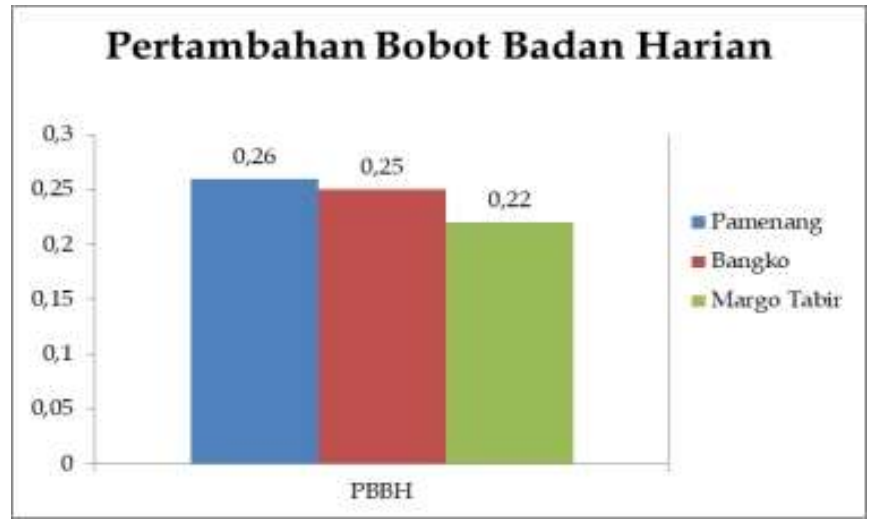

Gambar 3. Pertambahan bobot badan harian

Tabel 2 menunjukkan rataan BB sapi Bali di Kecamatan Pamenang, Kecamatan Bangko dan Kecamatan Margo Tabir pada penelitian ini berturut-turut adalah 206,07 $\pm 15,58 \mathrm{~kg} /$ ekor, $203,58 \pm 15,54 \mathrm{~kg} /$ ekor dan 190,37 $\pm 20,36$ $\mathrm{kg} /$ ekor. Hasil penelitian ini lebih tinggi bila dibandingkan dengan penelitian Latulumamina (2013) yaitu 187,00 $\pm 50,20$ kg/ekor. Rataan PBBH sapi Bali di Kecamatan Pamenang, Kecamatan Bangko dan Kecamatan Margo Tabir pada penelitian ini berturut-turut adalah

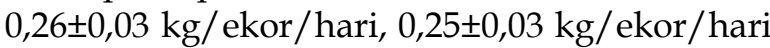
dan $0,22 \pm 0,05 \mathrm{~kg} /$ ekor/hari. Hasil penelitian ini lebih rendah bila dibandingkan dengan penelitian Rasyidah et al. (2018) yaitu 0,46 $\mathrm{kg}$ /ekor/hari.

Rataan BB dan PBBH sapi Bali di Kecamatan Pamenang berbeda tidak nyata $(P>0,05)$ dengan Kecamatan Bangko, namun berbeda nyata $(\mathrm{P}<0,05)$ dengan Kecamatan Margo Tabir. Rataan BB dan PBBH sapi Bali di
Kecamatan Bangko berbeda nyata $(\mathrm{P}<0,05)$ dengan Kecamatan Margo Tabir. Adanya perbedaan ini diduga disebabkan oleh perbedaan dari sistem breeding (perkawinan) yang diterapkan. Sistem perkawinan sapi Bali di Kecamatan Pamenang dan Bangko secara IB, sedangkan di kecamatan Margo Tabir sistem perkawinan secara alami. Sistem perkawinan secara inseminasi buatan memiliki beberapa keunggulan dibandingkan kawin alam, salah satunya dapat meningkatkan mutu genetik ternak melalui semen yang dipilih berasal dari pejantan yang sudah teruji. Menurut pendapat Djanah (1985) inseminasi buatan (IB) memiliki beberapa keunggulan bila dibandingkan kawin alami, diantaranya yaitu dapat memperbaiki mutu genetik, sebagai alat pengendalian penyakit, lebih efesien dan efektif dalam pemanfaatan semen, serta terbukanya kesempatan dalam memanfaatkan pejantan unggul. 
Di samping itu adanya perbedaan BB dan PBBH antar kecamatan Pamenang dan Bangko dengan kecamatan Margo Tabir diduga akibat adanya perbedaan sistem pemeliharaan. Menurut pendapat Masrah et al. (2016) sistem pemeliharaan intensif akan menghasilkan produktivitas yang lebih tinggi bila dibandingkan sistem pemeliharaan semi intensif dan ekstensif.

\section{Morfometrik sapi Bali di Tiga Kecamatan}

Rataan morfometrik sapi Bali di Kecamatan Pamenang, Kecamatan Bangko dan Kecamatan Margo Tabir disajikan pada Tabel 3.

Tabel 3. Rataan morfometrik sapi Bali di tiga kecamatan

\begin{tabular}{lcrc}
\hline Peubah & \multicolumn{3}{c}{ Sapi Bali } \\
\cline { 2 - 4 } & Kec. Pamenang & Kec. Bangko & Kec. Margo Tabir \\
\hline PB $(\mathrm{cm})$ & $114,30 \pm 3,79^{\mathrm{a}}$ & $113,18 \pm 3,15^{\mathrm{a}}$ & $110,63 \pm 3,01^{\mathrm{b}}$ \\
TP $(\mathrm{cm})$ & $104,87 \pm 2,62^{\mathrm{a}}$ & $104,85 \pm 3,78^{\mathrm{a}}$ & $102,03 \pm 2,81^{\mathrm{b}}$ \\
LD $(\mathrm{cm})$ & $140,83 \pm 3,92^{\mathrm{a}}$ & $139,78 \pm 4,67^{\mathrm{a}}$ & $137,05 \pm 3,31^{\mathrm{b}}$ \\
DaD $(\mathrm{cm})$ & $45,70 \pm 2,83^{\mathrm{a}}$ & $45,53 \pm 2,48^{\mathrm{a}}$ & $43,82 \pm 1,50^{\mathrm{b}}$ \\
LeD $(\mathrm{cm})$ & $33,65 \pm 1,79^{\mathrm{a}}$ & $32,97 \pm 2,12^{\mathrm{a}}$ & $30,93 \pm 1,22^{\mathrm{b}}$ \\
LK $(\mathrm{cm})$ & $14,25 \pm 0,99^{\mathrm{a}}$ & $14,18 \pm 0,67^{\mathrm{a}}$ & $13,07 \pm 0,75^{\mathrm{b}}$ \\
TPi $(\mathrm{cm})$ & $110,43 \pm 4,79^{\mathrm{a}}$ & $109,85 \pm 3,35^{\mathrm{a}}$ & $105,77 \pm 4,08^{\mathrm{b}}$ \\
\hline
\end{tabular}

Keterangan: $\mathrm{PB}=$ Panjang Badan, $\mathrm{TP}=$ Tinggi Pundak, $\mathrm{LD}=$ Lingkar Dada, DaD $=$ Dalam Dada, LeD = Lebar Dada, LK = Lingkar Kanon, TPi = Tinggi Pinggul.

Superskrip yang berbeda pada baris yang sama menunjukan hasil yang berbeda nyata $(\mathrm{P}<0,05)$.

Tabel 3 menunjukkan morfometrik sapi Bali di Kecamatan Pamenang berbeda tidak nyata $(P>0,05)$ dengan Kecamatan Bangko, akan tetapi berbeda nyata $(\mathrm{P}<0,05)$ dengan Kecamatan Margo Tabir. Gambar 4 menunjukkan morfometrik sapi Bali di Kecamatan Pamenang lebih tinggi dibandingkan sapi Bali di Kecamatan Bangko, kemudian yang paling rendah yaitu sapi Bali di Kecamatan Margo Tabir.

Perbedaan tersebut diduga karena adanya pengaruh dari perbedaan kondisi lingkungan, meskipun ketiga populasi tersebut berasal dari bangsa yang sama, namun dikarenakan ketiga populasi tersebut memiliki perbedaan kondisi lingkungan, maka potensi genetik yang dimiliki ternak juga berbeda. Kondisi lingkungan yang baik dapat memaksimalkan kemampuan genetik dalam mengekspresikan morfometrik pada setiap individu, begitupun sebaliknya apabila kondisi lingkungan yang tidak mendukung maka akan berdampak pada potensi genetik yang dimiliki setiap individu tidak dapat dimaksimalkan. Menurut pendapat Hikmawaty et al. (2018) faktor genetik dapat memengaruhi perbedaan morfometrik antar individu sapi. Namun, faktor lingkungan juga berperan dalam memaksimalkan kapasitas genetik dari suatu ternak, dengan demikian kondisi lingkungan yang ideal sangat dibutuhkan.

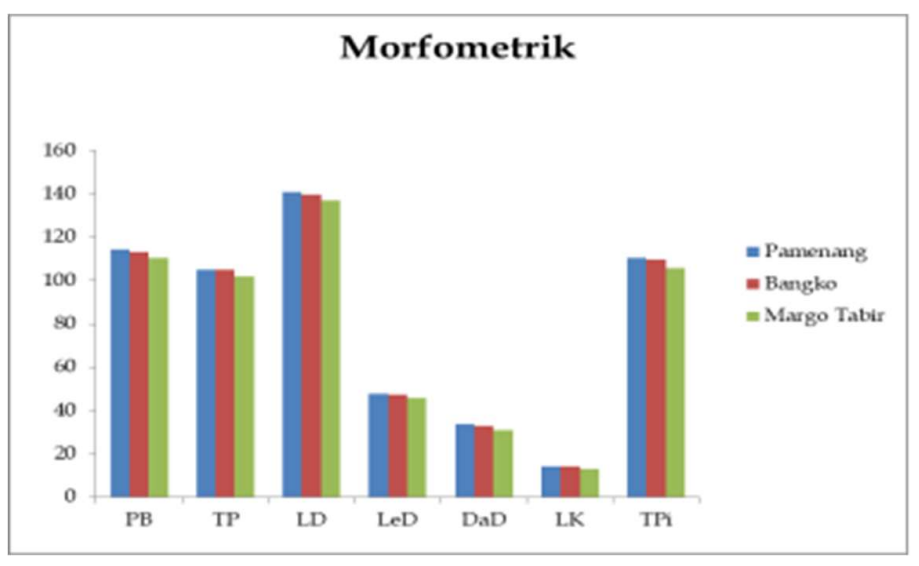

Gambar 4. Morfometrik sapi Bali antar kecamatan 


\section{Uji T2-Hotteling}

Uji statistik $\mathrm{T}^{2}$-Hotteling bertujuan untuk mengetahui adanya kesamaan dan perbedaan morfometrik antara dua populasi ternak. Uji $\mathrm{T}^{2}$ Hotteling juga dapat membandingkan ukuran sifat-sifat dua populasi secara bersamaan (Gaspersz., 2006). Hasil uji T2-Hotteling morfometrik sapi Bali antar kecamatan disajikan pada Tabel 4.

Tabel 4. T22-hotteling sapi Bali Kecamatan Pamenang, Bangko dan Margo Tabir

\begin{tabular}{lcccc}
\hline Populasi & Statistik T2-Hotteling & Nilai F & Nilai P & Kesimpulan \\
\hline BP-BB & 9,996 & 1,379 & 0,05 & tn \\
BP-BMT & 136,841 & 18,886 & 0,05 & $*$ \\
BB-BMT & 207,044 & 28,575 & 0,05 & $*$ \\
\hline
\end{tabular}

Keterangan: $\mathrm{BP}=$ Bali Pamenang, $\mathrm{BB}=$ Bali Bangko, $\mathrm{BMT}=$ Bali Margo Tabir, ${ }^{*}=$ Berbeda Nyata pada taraf $\mathrm{P}<0,05, \mathrm{tn}=$ berbeda tidak nyata pada taraf $\mathrm{P}>0,05$.

Tabel 4 menunjukkan morfometrik sapi Bali di Kecamatan Pamenang berbeda tidak nyata $(\mathrm{P}>0,05)$ dengan Kecamatan Bangko, namun berbeda nyata $(\mathrm{P}<0,05)$ dengan Kecamatan Margo Tabir. Berdasarkan hasil uji $\mathrm{T}^{2}$-Hotteling dapat diketahui morfometrik sapi Bali di Kecamatan Pamenang memiliki kesamaan dengan Kecamatan Bangko dan memiliki perbedaan dengan Kecamatan Margo Tabir. Perbedaan morfometrik sapi Bali di tiga kecamatan ini diduga dipengaruhi oleh perbedaan genetik dan lingkungan. Genetik yang baik akan berdampak positif untuk memaksimalkan laju pertumbuhan tulang, begitu juga dengan lingkungan harus dalam keadaan yang nyaman sehingga tidak menyebabkan stres pada ternak. Lingkungan meliputi manajemen pemeliharaan dan pakan, kualitas pakan seperti hijauan pakan ternak yang dapat memenuhi kebutuhan nutrient ternak juga dapat membantu meningkatkan laju pertumbuhan tubuh ternak. Hamdani et al. (2017) menjelaskan perbedaan morfometrik seperti panjang badan, lingkar dada dan tinggi pundak pada suatu ternak dapat dipengaruhi oleh beberapa faktor yaitu genetik, lingkungan, manajemen dan jenis kelamin.

\section{Analisis Komponen Utama}

Fungsi diskrimin antara penciri ukuran dan penciri bentuk tubuh ternak sapi dapat diketahui dengan menggunakan Analisis Komponen Utama (AKU). Sapi Bali di tiga kecamatan Kabupaten Merangin akan membentuk suatu persamaan ukuran dan bentuk tubuh, keragaman total (KT), serta nilai eigen $(\lambda)$ yang disajikan pada Tabel 5 .

Tabel 5. Persamaan ukuran dan bentuk tubuh sapi Bali di tiga kecamatan

\begin{tabular}{|c|c|c|c|c|c|}
\hline Kecamatan & & & Persamaan & KT (\%) & $\lambda$ \\
\hline \multirow{2}{*}{ Pamenang } & $\begin{array}{l}\text { Ukuran } \\
\text { Tubuh }\end{array}$ & $=$ & $\begin{array}{l}\text { 0,391 PB + 0,270 TP + 0,401 LD + 0,372 DaD + 0,400 LeD } \\
+0,394 \mathrm{LK}+0,400 \mathrm{TPi}\end{array}$ & 70,9 & 49,64 \\
\hline & $\begin{array}{l}\text { Bentuk } \\
\text { Tubuh }\end{array}$ & $=$ & $\begin{array}{l}(-) 0,018 \mathrm{~PB}+\mathbf{0 , 9 1 6} \mathrm{TP}-0,238 \mathrm{LD}-0,065 \mathrm{DaD}-0,178 \mathrm{LeD} \\
+0,112 \mathrm{LK}-0,235 \mathrm{TPi}\end{array}$ & 10,4 & 0,73 \\
\hline \multirow{2}{*}{ Bangko } & $\begin{array}{l}\text { Ukuran } \\
\text { Tubuh }\end{array}$ & $=$ & $\begin{array}{l}\text { 0,396 PB + 0,232 TP + 0,403 LD + 0,401 DaD + 0,387 LeD } \\
+0,393 \mathrm{LK}+0,402 \mathrm{TPi}\end{array}$ & 83,8 & 58,63 \\
\hline & $\begin{array}{l}\text { Bentuk } \\
\text { Tubuh }\end{array}$ & $=$ & $\begin{array}{l}(-) 0,491 \mathrm{~PB}+\mathbf{0 , 9 7 1} \mathrm{TP}-0,052 \mathrm{LD}-0,099 \mathrm{DaD}-0,102 \mathrm{LeD} \\
-0,081 \mathrm{LK}-0,095 \mathrm{TPi}\end{array}$ & 10,4 & 0,72 \\
\hline \multirow{2}{*}{ Margo Tabir } & $\begin{array}{l}\text { Ukuran } \\
\text { Tubuh }\end{array}$ & $=$ & $\begin{array}{l}\text { 0,383 PB + 0,305 TP + 0,410 LD + 0,400 DaD + 0,389 LeD } \\
+0,374 \mathrm{LK}+0,376 \mathrm{TPi}\end{array}$ & 80,6 & 56,45 \\
\hline & $\begin{array}{l}\text { Bentuk } \\
\text { Tubuh }\end{array}$ & $=$ & $\begin{array}{l}\text { (-)0,334 PB + 0,928 TP - 0,149 LD - 0,116 DaD - 0,199 LeD } \\
+0,033 \mathrm{LK}+0,025 \mathrm{TPi}\end{array}$ & 7,7 & 0,53 \\
\hline
\end{tabular}

Keterangan: $\mathrm{PB}=$ Panjang Badan, TP = Tinggi Pundak, LD = Lingkar Dada, DaD = Dalam Dada, LeD = Lebar Dada, LK = Lingkar Kanon, TPi = Tinggi Pinggul. 
Tabel 5. menunjukan Keragaman Total (KT) pada komponen utama pertama yang menghasilkan nilai terbesar diantara tiga kecamatan adalah KT sapi Bali yang berada di Kecamatan Bangko dengan nilai sebesar 83,8\%. Artinya dari nilai eigen yang paling tinggi didistribusikan pada komponen utama pertama sebanyak $83,8 \%$, sisanya yaitu $16,2 \%$ akan didisdribusikan ke komponen utama kedua sampai komponen utama ketujuh dan membentuk suatu persamaan sebagai berikut: $\lambda_{1}>\lambda_{2}>\lambda_{3} \ldots \lambda_{n}>0$. Hal ini sesuai dengan pendapat Heryani et al. (2018) bahwa hasil nilai ukuran dari keragaman total pada komponen utama pertama yaitu kisaran 50\%-90\%, sedangkan nilai bentuk dari keragaman total pada komponen utama kedua yaitu minimal hanya satu persen.

Tabel 6. Penentu ukuran dan bentuk tubuh sapi bali di tiga kecamatan

\begin{tabular}{llll}
\hline No & Kecamatan & Penciri ukuran & Penciri Bentuk \\
\hline 1 & Pamenang & Lingkar Dada & Tinggi Pundak \\
2 & Bangko & Lingkar Dada & Tinggi Pundak \\
3 & Margo Tabir & Lingkar Dada & Tinggi Pundak \\
\hline
\end{tabular}

Tabel 6 menunjukan vektor penentu ukuran tubuh sapi Bali di tiga Kecamatan Kabupaten Merangin adalah lingkar dada. Artinya lingkar dada dapat di jadikan sebagai penentu ukuran tubuh dari sapi Bali di Kecamatan Pamenang, Kecamatan Bangko, Kecamatan Margo Tabir. Baharun et al. (2018) menyatakan lingkar dada merupakan rataan linier tertinggi pada tubuh sapi Bali. Vektor penentu bentuk tubuh sapi Bali di tiga kecamatan Kabupaten Merangin adalah tinggi pundak. Artinya tinggi pundak dapat dijadikan sebagai penentu bentuk tubuh dari sapi Bali di Kecamatan Pamenang, Kecamatan Bangko, Kecamatan Margo Tabir.

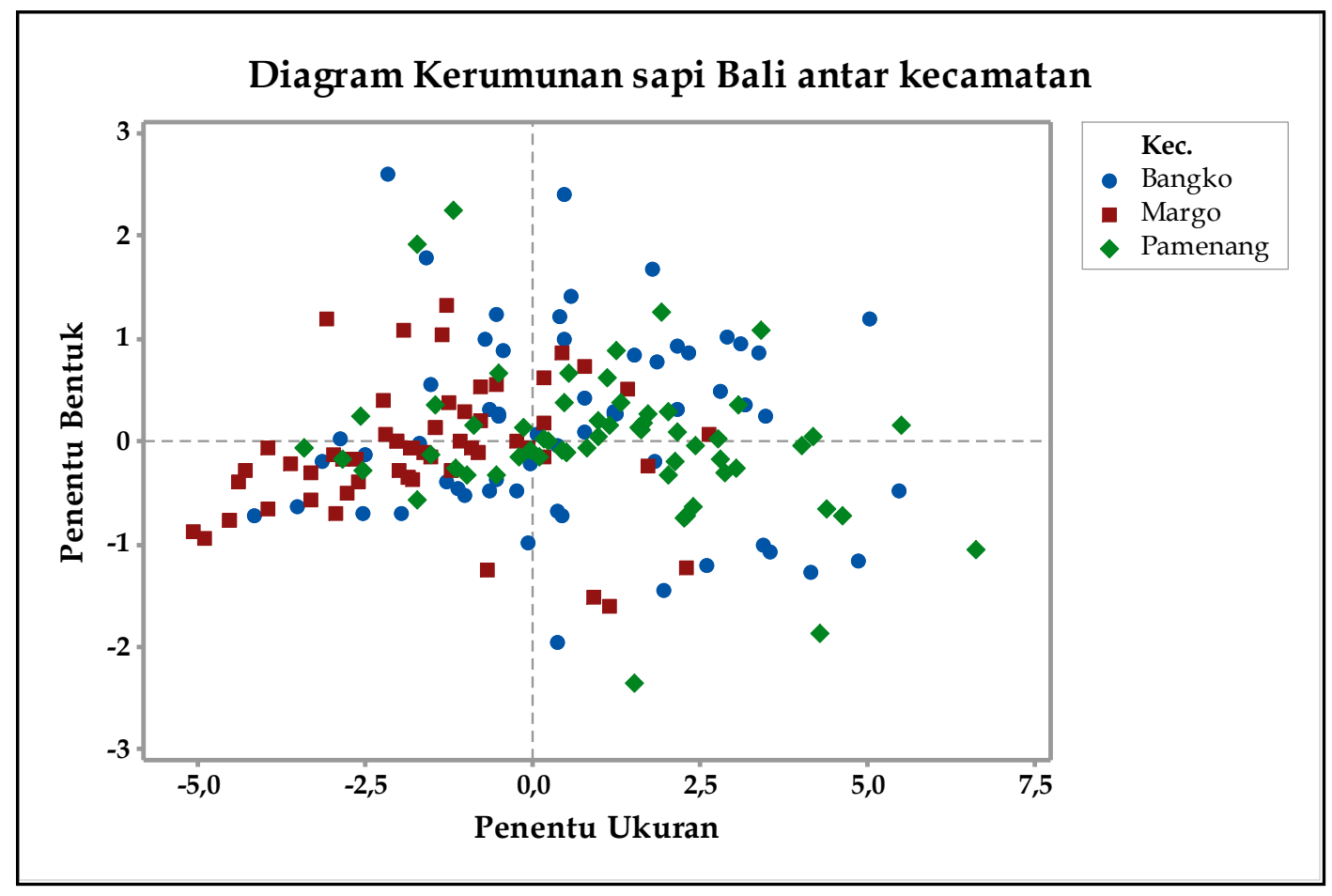

Gambar 5. Diagram kerumunan 
Gambar 5 menunjukkan skor ukuran dan bentuk tubuh sapi Bali di tiga kecamatan tersebut masih relatif sama. Hal ini diperlihatkan dari diagram kerumunan yang menunjukkan ada terjadinya tumpang tindih. Skor ukuran tubuh terendah dimiliki oleh populasi sapi Bali di Kecamatan Margo Tabir yang dapat dilihat pada sumbu X. Kecilnya penciri ukuran pada sapi Bali di Kecamatan Margo Tabir ini kemungkinan disebabkan oleh kuantitas pakan yang lebih rendah dibandingkan Kecamatan Pamenang dan Bangko.
Berdasarkan skor bentuk tubuh sapi Bali di Kecamatan Pamenang dan Bangko memiliki bentuk yang relatif sama dan lebih besar bila dibandingkan sapi Bali di Kecamatan Margo Tabir. Menurut Hikmawaty et al. (2014) kesamaan dari skor bentuk tubuh sapi Bali tersebut disebabkan kesamaan genetis yang dimiliki, kesamaan genetis berasal dari sumber bibit sapi Bali yang sama.

\section{Jarak Genetik}

Jarak genetik antara sapi Bali Kecamatan Pamenang, Kecamatan Bangko dan Kecamatan Margo Tabir disajikan dalam Tabel 7.

Tabel 7. Jarak genetik sapi Bali antar kecamatan

\begin{tabular}{llll}
\hline Kecamatan & Bali Pamenang & Bali Bangko & Bali Margo Tabir \\
\hline Pamenang & 0 & & \\
Bangko & 0,5772 & 0 & 0 \\
Margo Tabir & 2,1357 & 2,6270 & 0 \\
\hline
\end{tabular}
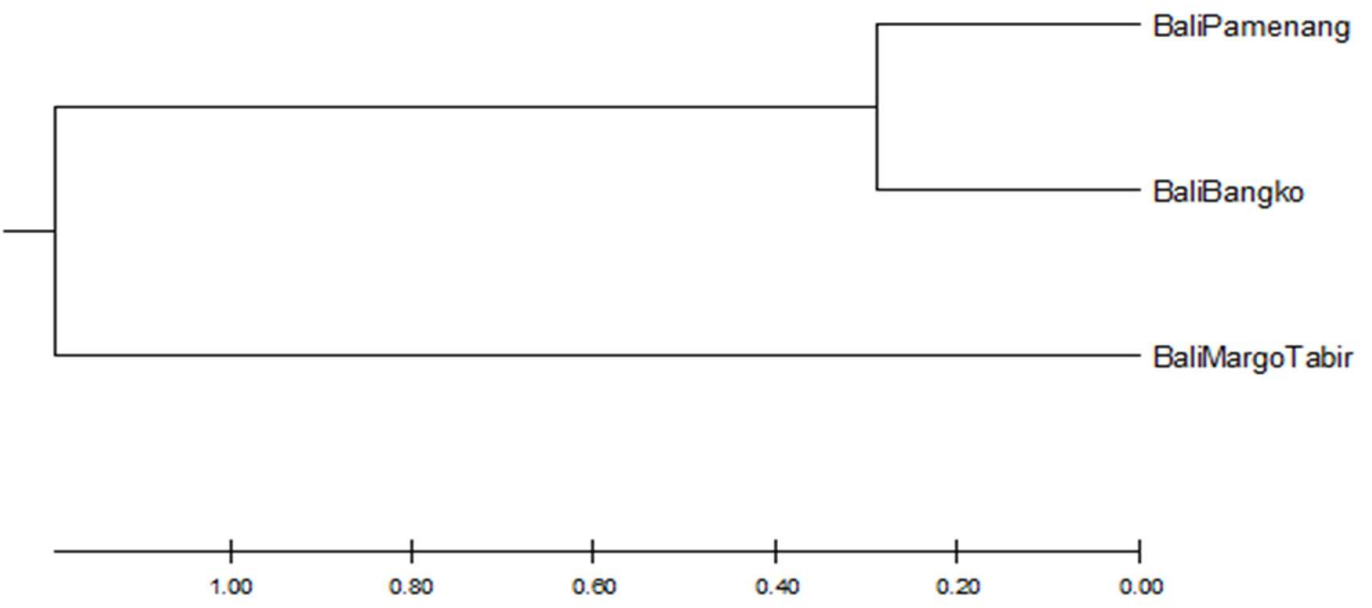

Gambar 6. Dendogram jarak genetik sapi Bali antar kecamatan

Tabel 7 menunjukkan bahwa berdasarkan morfometrik, nilai jarak genetik antara sapi Bali di Kecamatan Pamenang dan Bangko adalah 0,5772. Kecamatan Pamenang dan Margo Tabir adalah 2,1357 sedangkan pada Kecamatan Bangko dan Margo Tabir adalah 2,6271. Hubungan kekerabatan sapi Bali yang terdekat pada tiga kecamatan tersebut terdapat pada Kecamatan Pamenang dan Kecamatan Bangko. Sedangkan pada Kecamatan Margo Tabir dendogram yang digambarkan membentuk klaster yang berbeda dengan sapi Bali di
Kecamatan Pamenang dan Bangko, artinya sapi Bali di Kecamatan Margo Tabir memiliki hubungan kekerabatan yang jauh dibandingkan dengan sapi Bali di Kecamatan Pamenang dan Bangko.

Informasi jarak genetik dapat digunakan sebagai data dasar dalam upaya perbaikan mutu genetik ternak sapi Bali di Kabupaten Merangin. Selain itu, jarak genetik juga dapat dijadikan acuan untuk menentukan tindakan dalam program pemuliaan ternak yang berupa 
seleksi atau persilangan. Ukuran jarak genetik yang relatif dekat jika disilangkan diduga tidak akan mendapatkan kemajuan ukuran kuantitatif yang mengesankan, hal ini disebabkan oleh kecilnya sifat heterosis yang didapatkan karena keragaman genetik yang diperoleh masih relatif rendah yaitu hanya berasal dari dalam bangsa atau populasi tersebut. Sedangkan apabila jarak genetik yang relatif jauh jika disilangkan diduga dapat meningkatkan sifat heterosis yang lebih besar, hal ini disebabkan oleh keragaman genetik yang diperoleh yaitu relatif lebih tinggi karena perkawinan antar bangsa atau populasi lain. Menurut Anggraeni et al. (2011) menyatakan bahwa ternak yang memiliki hubungan kekerabatan yang jauh diperkirakan akan memperoleh sifat heterosis yang lebih besar dibandingkan dengan ternak yang memiliki hubungan kekerabatan yang dekat.

Berdasarkan Gambar 6 dapat diketahui bahwa salah satu upaya yang dapat dilakukan untuk perbaikan mutu genetik sapi Bali di Kecamatan Margo Tabir yaitu dengan menyilangkan induk sapi Bali pada Kecamatan Margo Tabir dengan pejantan di Kecamatan Pamenang dan Bangko. Tindakan ini dilakukan dengan harapan dapat meningkatkan keragaman genetik pada Kecamatan Margo Tabir, sehingga sifat heterosis yang didapatkan akan lebih besar. Sedangkan untuk meningkatkan mutu genetik sapi Bali di Kecamatan Pamenang dan Bangko dapat dilakukan dengan mendatangkan pejantan unggul atau semen yang berasal dari pejantan unggul yang telah teruji dengan syarat bahwa pejantan yang didatangkan tidak memiliki hubungan genetik dengan kedua populasi tersebut.

\section{KESIMPULAN}

Performa sifat kuantitatif tertinggi yang meliputi bobot badan, pertambahan bobot badan harian dan morfometrik ditemukan pada populasi sapi Bali di Kecamatan Pamenang dan Kecamatan Bangko dan paling rendah adalah sapi Bali di Kecamatan Margo Tabir. Penciri ukuran tubuh sapi Bali di Kecamatan Pamenang, Kecamatan Bangko dan Kecamatan Margo Tabir adalah lingkar dada. Penciri bentuk tubuh sapi Bali di Kecamatan
Pamenang, Kecamatan Bangko dan Kecamatan Margo Tabir adalah tinggi pundak. Jarak genetik yang terjauh yaitu antara sapi Bali Bangko dan Margo Tabir (2,6271), sedangkan yang terdekat yaitu antara populasi sapi Bali di Kecamatan Pamenang dan Kecamatan Bangko $(0,5772)$, jarak genetik sapi Bali Pamenang dan Margo Tabir $(2,1357)$.

\section{KONFLIK KEPENTINGAN}

Bersama pernyataan ini penulis dan seluruh anggota tim peneliti menyatakan tidak sedang memiliki konflik kepentingan yang berhubungan dengan keuangan, pribadi, atau lainnya dengan orang atau organisasi lain yang terkait dengan materi yang dibahas dalam naskah.

\section{UCAPAN TERIMA KASIH}

Terima kasih kepada Kepala Dinas Peternakan dan Perkebunan Kabupaten Merangin dan Kepala UPTD Desa Pinang Merah yang sudah berkenan dan mengizinkan penulis untuk melakukan penelitian di wilayah kerjanya.

\section{DAFTAR PUSTAKA}

Abdurrachman, S. H., H. Komalig, \& N. Nainggolan. 2014. Penggunaan analisis komponen utama dalam penggabungan data peubah ganda pada kasus produksi pertanian dan perkebunan di wilayah Bandung Mongondow tahun 2008. Jurnal d'Cartesian. 3 (2): 1-8.

Anggraeni A, C. Sumantri, L. Praharani, E. Andreas. 2011. Genetic distance estimation of local swamp buffaloes through morphology analysis approach. Jurnal Ilmu Ternak dan Veteriner. 16(3): 199-210.

Badan Pusat Statistik Indonesia. 2018. Indonesia Dalam Angka: Badan Pusat Statistik Indonesia.

Badan Pusat Statistik Kabupaten Merangin. 2018. Kabupaten Merangin Dalam Angka: Badan Pusat Statistik Kabupaten Merangin.

Badan Pusat Statistik Provinsi Jambi. 2018. Provinsi Jambi Dalam Angka: Badan Pusat Statistik Provinsi Jambi. 
Baharun, A., H. L. L. Belli, \& T. M. Hine. 2017. Karakteristik pejantan muda sapi Bali pada peternakan raktyat di desa Merbaun kabupaten Kupang. Jurnal Peternakan Nusantara. 3(1): 11-16.

Depison. 2010. Performans anak hasil persilangan induk sapi bali dengan beberapa bangsa pejantan di kabupaten Batanghari Provinsi Jambi. Jurnal Agripet. 10(1): 37-41.

Djanah, D. 1985. Mengenal Inseminasi Buatan. CV. Simplex. Jakarta.

Gaspersz, V. 2006. Teknik Analisis dalam Penelitian Percobaan. $3^{\text {rd }}$ ed. Tarsito, Bandung.

Hamdani, M. D. I., K. Adhianto, Sulastri, A. Husni, \& Renitasari. 2017. Ukuran ukuran tubuh sapi bali krui jantan dan betina di kabupaten Pesisir Barat Lampung. Jurnal Ilmu Ternak. 17(2): 97-102.

Heriyadi, D. 2012. Modul I Produksi Domba dan Kambing. Laboratorium Produksi Ternak Potong Fakultas Peternakan Universitas Padjajaran. Bandung.

Heryani, L. G. S., N. N. W. Susari, \& I. W. N. F. Gunawan. 2018. Variabel komponen utama pada morfometrik sapi putih taro berdasarkan pengukuran badan. Buletin Veteriner Udayana. 10(1): 93-99.

Hikmawaty, A. Gunawan, R. R. Noor, \& Jakaria. 2014. Identifikasi ukuran tubuh dan bentuk tubuh sapi Bali di beberapa pusat pembibitan melalui pendekatan analisis komponen utama. Jurnal Ilmu Produksi dan Teknologi Hasil Peternakan. 2(1): 231-237.

Hikmawaty, Bellavista, T. A. B. A. Mahmud, \& A. Salam. 2018. Korelasi bobot badan dan variabel variabel ukuran tubuh sebagai dasar seleksi calon induk sapi Bali. Jurnal Ilmu Pertanian Universitas Al Asyariah Mandar. 3(1): 11-13.

Komariah. 2016. Produktivitas kerbau lumpur berdasarkan agrosistem dan strategi pengembangannya di kabupaten Cianjur. Jurnal Veteriner. 16(4): 606-615.

Latulumamina, M. 2013. Korelasi antara umur dan berat badan sapi bali (Boss sondaicus) di Pulau Seram. Jurnal Ilmu Ternak dan Tanaman. 3(1): 35-40.

Masrah, M., H. Hafid, \& T. Saili. 2016. Kajian produktivitas ternak kambing pada sistem pemeliharaan yang berbeda di kecamatan Andoolo Barat kabupaten Konawe Selatan. Jurnal Ilmu dan Teknologi Peternakan Tropis. 3(1): 1-7.

Pinem, U., Hamdan, \& N. D. Hanafi. 2015. Estimasi jarak genetik dan faktor peubah pembeda rumpun kelinci melalui analisis morfometrik. Jurnal Peternakan Integratif. 2 (3): 264-286.

Rasyidah, M., M. B. Paly, K. Kiramang, \& R. Nurhidayat. 2018. Pengaruh pemberian alga coklat terhadap pertambahan berat badan sapi Bali jantan. Jurnal Ilmu dan Industri Peternakan. 4(2): 139-148. 